\title{
A PRELIMINARY REPORT ON THE PLYMOUTH MARINE AND BRACKISH-WATER ROTIFERA
}

\author{
By E. D. Hollowday, F.R.M.S.
}

(Text-figs. I-2)

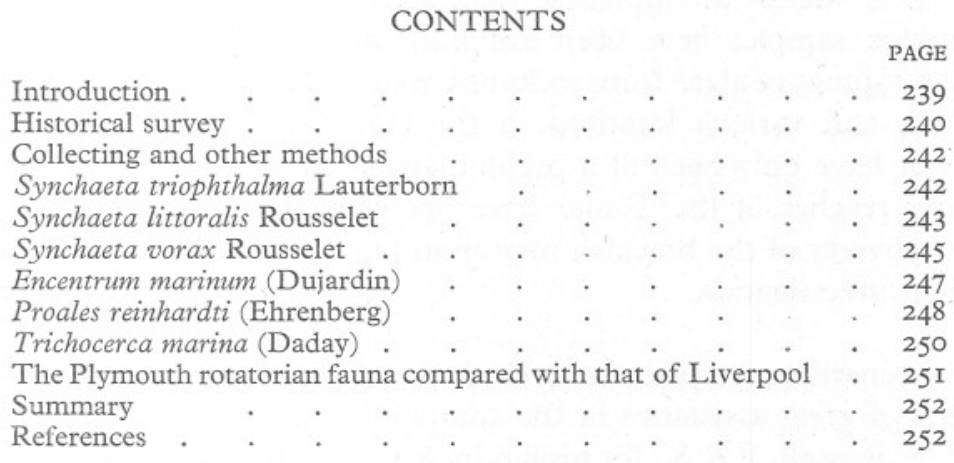

\section{INTRODUCTION}

Throughout the sixty odd years during which the Plymouth Laboratory has been the centre of the scientific investigation of British marine life, especially that of Plymouth Sound and neighbouring areas, there has only been one species of rotifer recorded, ${ }^{1}$ namely Synchaeta gyrina Hood (Marine Biological Association, I93I, p. I49), but some doubt is cast on the accuracy of this identification by the mention of it occurring 'with eggs'. It is a well-established fact that $S$. gyrina does not carry its eggs after extrusion, but drops them immediately, although several closely related species are known to carry the eggs attached to the cloaca until they hatch. On the other hand, 'with eggs' may possibly mean that specimens were observed with the egg developing within the ovisac, in which event there is no objection to the identification. Anyhow, it is highly probable that $S$. gyrina actually occurs either in the Sound or the Hamoaze, although it was not observed during the writer's survey.

The dearth of information on the Plymouth brackish and marine Rotifera is probably not so surprising as it may at first appear, as none of the pelagic

\footnotetext{
${ }^{1}$ Shortly after completing this report, two unpublished records by the late David Bryce were forwarded to the writer from the Plymouth Laboratory. These relate to the occurrence of Synchaeta vorax and S. triophthalma in the Sound during April 1934, and there is a doubtful record of S. cecilia Rousselet occurring beyond the Plymouth breakwater in March of the same year. Although this species was not refound by the writer, it is common in the Liverpool area (per A. L. Galliford) and it is highly probable that it does occur at Plymouth.
} 
species found by the writer (with the possible exception of $S$. vorax Rousselet) ever become really numerous in the plankton, and, furthermore, there have been no serious students of the rotifers round our coasts since the death of Charles Rousselet, and very few before him. It is quite likely that workers at the laboratory specializing in plankton studies occasionally come upon rotifers in tow-net samples, but, being occupied with other forms, pay little attention to them. If this is so, the writer would gladly welcome rough sketches of any species noticed by workers on other phyla during their studies.

The writer wishes to emphasize that, although a considerable number of fine plankton samples have been examined at all times of the year, not to mention scrapings of algae from rocks and rock pools, at Jenny Cliff, Rum Bay, Barn Pool, and various locations in the Hamoaze, etc., the investigations carried out have only been of a preliminary nature. The Yealm, Cattewater, and upper reaches of the Tamar have not been looked into at all, and the apparent poverty of the brackish rotatorian fauna at Plymouth may be due to insufficient investigation.

The writer wishes to place on record his very deep gratitude to those who have been of great assistance in the compilation of this preliminary survey; to Mr F. S. Russell, F.R.S., for his kindness in allowing the writer unrestricted facilities at the Plymouth Laboratory; to Dr M. V. Lebour for a tube of preserved Synchaeta from Plymouth Sound plankton samples; to Mr S. M. Nunn for setting aside plankton samples from the laboratory's boats as required; and to Mr A. L. Galliford of Liverpool to whom the writer is indebted for general information on many aspects of the study of rotifers, for placing at his disposal information concerning the coastal Rotifera of the Liverpool area, for advice, and also for checking and criticizing the present report.

\section{HISTORICAL SURVEY}

Our knowledge of marine and brackish-water Rotifera dates back to the first half of the nineteenth century. In I830, a certain Dr Michaelis collected a species of Synchaeta (which has more marine and brackish representatives than any other known genus of rotifers) in Kiel harbour. This discovery, and its subsequent publication as Synchaeta baltica by C. von Ehrenberg (1834, p. 220), led to a great deal of confusion regarding the identity of several other species of Synchaeta found in coastal waters during the next sixty years, and the matter was not really cleared up until Charles Rousselet (1902) published his monograph on the genus. The writer has not had access to the original description of S. baltica. In his Die Infusionsthierchen of I838 (p. 439; Pl. 53, fig. 5), Ehrenberg is mainly concerned with the rotifer's supposed luminosity, originally suggested by Michaelis, but finds little support for the theory. The luminosity was doubtless due to the presence in the same water of 
phosphorescent dinoflagellates, which, Ehrenberg states, were collected with the rotifers. Even so, P. H. Gosse (I856, p. 274, pl. xiv), and several other workers, apparently clung to the idea of Synchaeta spp. being responsible for luminous phenomena in coastal waters. Rousselet (1902) states, however, that 'there is no valid reason for the statement that this Synchaeta, or any other rotifer, is connected with the luminosity of the sea'.

During the period I838-60, little work appears to have been done, apart from the occasional papers of P. H. Gosse and Dujardin, but in I886, Hudson \& Gosse published their monograph The Rotifera or Wheel Animalcules, and the supplement issued in 1889 contains drawings and descriptions of several species which Gosse had found in tidal pools along the Devon coast. Some of these are also known from fresh-water habitats. The publication of The Rotifera stimulated a great interest on the part of amateurs and professionals alike during the closing years of the nineteenth century. On the continent Dr Karl Zelinka, Dr Plate, and Zacharias, not to mention K. M. Levander and Robert Lauterborn, considerably advanced rotatorian anatomy, physiology, ecology and taxonomy; while John Hood, Charles Rousselet, and David Bryce extended our knowledge of the British fauna. Nearly all the above-mentioned workers described coastal forms, and in the report of the German plankton expedition of I895 (Zelinka, 1907) is published a description and figure of a new species of Synchaeta, namely $S$. atlantica, which was collected at several stations in mid-Atlantic.

The years 1859 , I868, and 1876 are important milestones in the study of coastal Rotifera. In I859, A. E. Grube published a description of a peculiar rotifer, Seison nebaliae, found as an ecto-parasite (probably only commensal) on the malacostracous crustacean Nebalia. In 1876, Claus described another species of this genus. In I868, E. Ray Lankester described a rotifer, now known as Zelinkiella (Discopus) synaptae, from the alimentary canal of a sea cucumber. These two genera, along with the genus Paraseison, are the only exclusively marine rotatorian genera. The above-mentioned rotifers are highly specialized, and it is likely that careful examination of macroscopic marine animals may reveal further parasitic and commensal rotifers.

The published work on the Rotifera since the first years of the present century has been mainly devoted to the physiology, ecology and systematics of freshwater forms, the only marine studies being those of Remane (1929) at Kiel, Wulfert (I942) in Germany and Italy, and Galliford (I945, I946) in Liverpool Bay and along the Cheshire coast. A preliminary survey of rotifers from tidal pools at Millport was made by the late David Bryce in 1927 (Scottish Marine Biological Association, 1928). 


\section{Collecting and OTHER Methods}

As with most other forms of life, the methods and apparatus used in collecting rotifers have to be varied according to the habitat. The pelagic species were collected by fine bolting-silk tow-nets, either from the laboratory's boat or by the writer from a rowing boat. The former collections were made at various stations in Plymouth Sound, from inshore to beyond the breakwater. The writer's own plankton hauls were made in the mouth of the Tamar, at various points in the Hamoaze, and from Drake's Island to the shore. Scrapings of algae from tidal pools and crevices along the shore at Barn Pool, Cremyl, Rum Bay, Jennycliff Bay, and the Royal William Victualling Yard wharfs, were taken and examined for the weed-haunting littoral forms. Masses of Fucus from all the above-mentioned stations were washed and squeezed through bolting silk in order to dislodge browsing forms. Collections were also made with a hand-net of fine bolting silk in the creek known as Stonehouse Lake.

Samples were always examined in fresh condition. It is a great mistake to preserve plankton samples when searching for Rotifera if there is any means of examining them within a reasonable time. This applies not only to marine, but to brackish and fresh-water samples also. Indeed, it is highly probable that many rotifers are overlooked by workers who would otherwise notice them, as a result of specimens being contracted or otherwise distorted through preservation. Furthermore, and this applies especially to the genus Synchaeta, it is usually impossible to detemine species from contracted specimens, and often, when the animal is very transparent and lying amongst flocculent debris, etc., it is very difficult to distinguish it as a rotifer at all. When located, however, and after careful note has been taken of external appearances, it is often necessary to kill the animal and dissolve out the jaws or trophi with a solution of sodium or potassium hydroxide. Samples were first examined in a glass dish under the low power of a dissecting microscope, and individual specimens transferred with a fine pipette to a Rousselet compressorium for detailed study. All drawings were made from living specimens while held still in the compressorium, the method of drawing being that described by the writer (Hollowday, I946).

\section{Synchaeta triophthalma Lauterborn (Fig. I A, B).}

Lauterborn, R., I894. Wiss. Meeresunters. Biol. Anst., Abt. Helgoland, Bd. pp. 207-13, fig. I.

S. triophthalma was originally found in I893 by Dr Lauterborn off the coast of Heligoland, and subsequently by John Hood in the sea off Dundee. A brackish-water species, it has now been recorded from the Bay of Naples, Trieste, the Skagerak, Bergen, Liverpool and the Cheshire coast, where it is found in rock pools on Hilbre Island. It has recently also been recorded from New Zealand, in Oamuru Harbour. 
At Plymouth it occurred in Stonehouse Lake, a tidal creek opening on Plymouth Sound between Plymouth and Devonport. It is quite probable that this species is common in brackish situations all round our coasts.

It occurred at Plymouth in April 1946, only female specimens being observed, and most of these carried eggs. As far as the writer is aware, the male is as yet unknown. The eggs carried by these Stonehouse specimens were of the ordinary, parthenogenetic type. According to Rousselet, $S$. triophthalma dies almost immediately if placed in fresh water, but, on the other hand, it never seems to occur in water of a very high salinity, preferring rock pools above the highwater mark, or in the 'splash' or 'spray zone', or the upper reaches of creeks and river estuaries. It was never observed in the Hamoaze or the Sound.

S. triophthalma is fairly easy to recognize, being extremely wide anteriorly, possessing, as a rule, three main pigment spots. A rather unique feature is the asymmetrical left lateral antenna, situated, not in the usual position (the lumbar region), but on a prominent swelling on the left dorso-lateral surface of the foot. According to Rousselet, the right lateral antenna is absent, but the writer has recently been informed by Mr A. L. Galliford that Remane has found what he believes to be the right lateral antenna in the normal position, but very inconspicuous, and without the brush of sensory setae. Nothing was seen of this in the Plymouth specimens.

The foot terminates in a single pointed toe (Fig. I B).

\section{Synchaeta littoralis Rousselet (Fig. IC).}

Rousselet, C., 1902. Fourn. Micr. Soc., p. 398, pl. vii, fig. 15 .

While apparently a rare rotifer in Plymouth Sound and the Hamoaze, this species is reported common in brackish water at Leasowe, Cheshire, by $\mathrm{Mr}$ Galliford, and the accompanying illustration was drawn from a Leasowe specimen. It has been observed only once or twice at Plymouth, occurring in fine tow-net samples collected by the motor boat Gammarus between Drake's Island and the Hoe in May and June 1947.

The size of this species seems rather variable. Rousselet gives the maximum length as $238 \mu$. The specimen here depicted, and most of the other Leasowe specimens measured I $92 \mu$ or thereabouts, and the Plymouth Sound specimens agreed with this.

The body is stouter than in S. triophthalma, being more cylindrical in shape. There are two streams of purple granules connecting the frontal eyespots with the occipital. The lateral antennae are placed some three-quarters of the way down towards the foot, at the point where the trunk begins to narrow. No males were observed at Plymouth.

Originally described by Rousselet from specimens collected at Dundee by Hood, it has been found at Great Yarmouth, Margate and Leasowe, Cheshire. There is a doubtful record for Naples. 


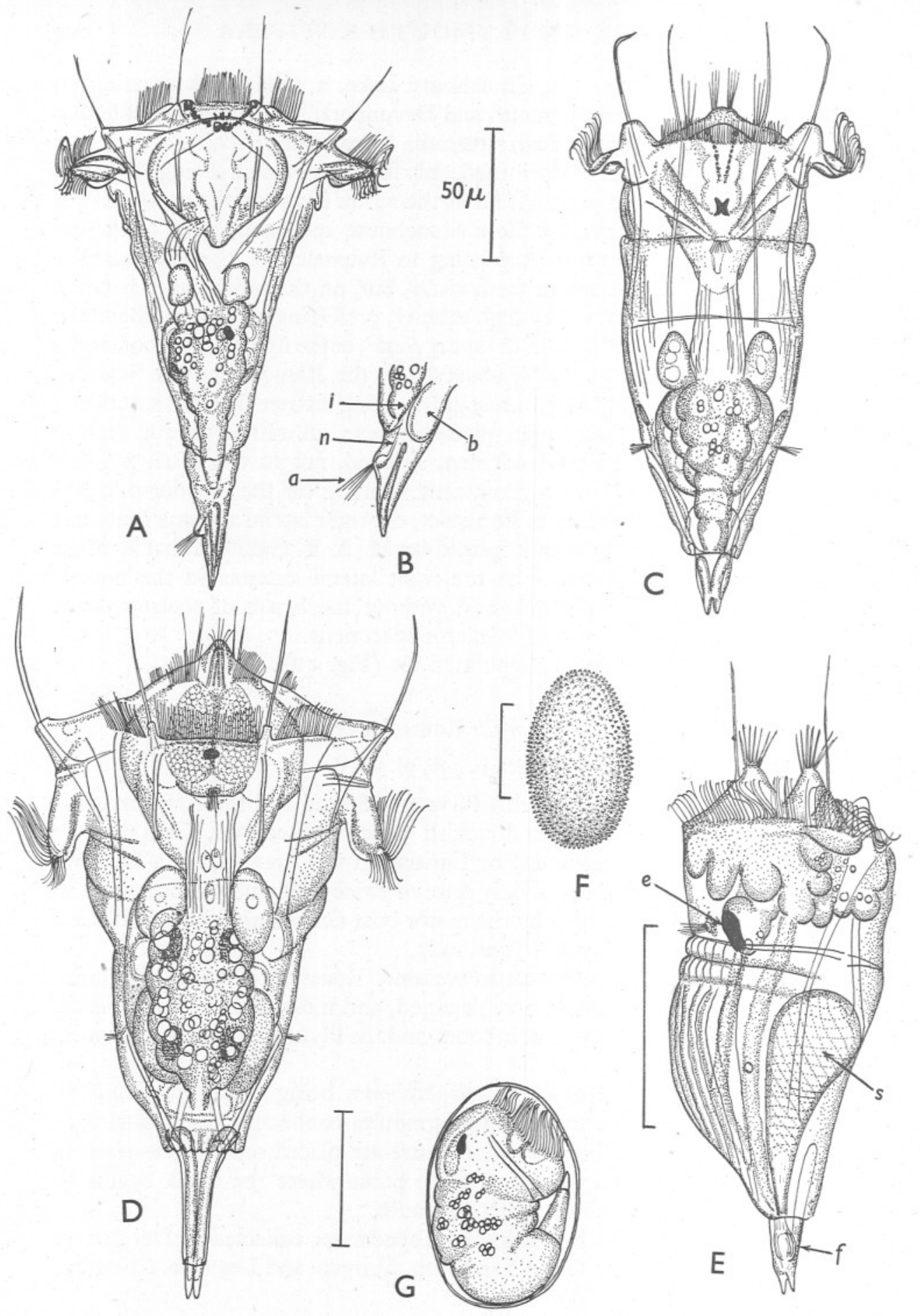

Fig. I. 


\section{Synchaeta vorax Rousselet (Fig. I D-G, 2A).}

Rousselet, C., 1902. Fourn. R. Micr. Soc., pp. 408-10, pl. viii, fig. 19.

This species has been more thoroughly investigated by the writer at Plymouth than any other rotifer. It is not only common in the inshore waters of the Sound, but occurs also beyond the breakwater for considerable distances. Its presence in large numbers in all fine tow-net collections, during the summer months, must have been noticed by many workers studying fresh plankton samples at Plymouth. It is probably this species which Lebour records 'occasionally in tow-nets from the Sound' (Marine Biological Association, I93I, p. I49).

\section{Occurrence and swarming periods at Plymouth}

$S$. vorax was numerous in the first plankton samples collected by the writer from a rowing boat beyond Drake's Island in April I946. Fig. I D was drawn from a specimen in this first collection. It subsequently occurred in samples collected by the laboratory boat beyond the breakwater, although somewhat sparingly. Owing to the writer's preoccupation with other groups, no further records were made during 1946, but this was doubtless due to the fact that only medium tow-net samples were examined. During I947, however, the rotifer was closely studied from February until its climax and sudden disappearance in May. Owing to extremely adverse weather conditions early in the year, no collections were made before February, so it is not possible to say exactly when it reappears from the previous summer's resting eggs. It was present in very small numbers during February, increasing steadily throughout March and April, and by the middle of May it was, on several occasions, easily the most numerous member of the zooplankton in fine tow-net collections. Mr P. S. B. Digby informed the writer about this time, that he had recently found it very numerous while studying copepods from the Sound.

About the time that $S$. vorax reached its climax, in the middle of May, there appeared in the Sound great quantities of the alga Phaeocystis poucheti Langerh., and it was a common sight to see many Synchaeta vorax madly tearing away with their protruded unci at the cells round the outer margins of

Fig. I. A, Synchaeta triophthalma Lauterborn; $\$$ from Stonehouse Lake, Plymouth; length I90 $\mu$; dorsal aspect. B, the same, enlarged lateral aspect of 'foot'. C, S. littoralis Rousselet; + from Leasowe, Cheshire; length I92 $\mu$; dorsal aspect. D, $S$. vorax Rousselet; o from Plymouth Sound, Apr. 1946; length, with foot extended, $250 \mu$. E, the same; 0 from Plymouth Sound, May I947, showing the 'foot' extended; length I29 $\mu$; left dorso-lateral aspect. F, the same, resting egg deposited in Phaeocystis, Plymouth Sound, May I947; length $93 \mu$. G, the same, developing egg showing ô shortly due to hatch, length $84 \mu$. $a$, antenna; $b$, bladder; $e$, eye spot; $f$, foot; $i$, intestine; $n$, nerve; $s$, sperm sac. Vertical scales all represent lengths of $50 \mu$. 
the colonies. This went on for over a week, and then males appeared in large numbers. It must be noted that the writer never actually witnessed copulation, which is usually a necessary observation before deciding on the identity of most male rotifers, but these males agreed in most respects with the details given by Rousselet; furthermore, there were no females of any other species of Synchaeta present at the time, and almost immediately after these males appeared, the $S$. vorax began to lay resting eggs (a result of fertilization), these being deposited in the gelatinous masses of the Phaeocystis. The rotifer disappeared with a suddenness quite common in plankton rotifers; samples collected on 23 May 1947 being entirely devoid of a single active specimen, although many resting eggs still remained in the masses of Phaeocystis.

For over a year after first collecting this species at Plymouth, the writer was undecided as to its specific identity, and although the final decision was agreed to by Mr Galliford (who has studied the species fairly extensively at Liverpool), after much discussion and detailed study of all available literature, drawings, and Rousselet's own mounted specimens, there are one or two points wherein the Plymouth specimens differ from Rousselet's original published description and the accompanying figures.

First of all, it would appear that there are two distinct forms of Synchaeta vorax differing in the size of the whole animal, and in the proportions of the foot. In all other respects, these two forms are identical. The Plymouth specimens all measured an average of $250 \mu$, being possessed of a long slender foot. This size compares well with the average of $272 \mu$ given in the original description, and the $238 \mu$ which is the greatest length of some specimens mounted by Rousselet himself in 1899 and recently examined by the writer. At Southport and Liverpool, however, Mr Galliford finds a smaller form which has a somewhat stouter foot than those at Plymouth, being more in keeping with the original description and drawing in this respect, but measuring only $200 \mu$. Another slide mounted by Rousselet, and lodged at the Manchester University, shows specimens with a fairly stout foot and a total length which varies from $196 \mu$ to $216 \mu$.

Another slight difference in the Plymouth specimens was their apparent 'calmness', which is certainly not in keeping with the wild, voracious habits ascribed to the species by Rousselet, and faithfully exhibited by the specimens from the Lancashire coast. Indeed, Rousselet had good reasons for adopting the specific name vorax, and in his original description he says: 'the species swims with such impetuosity through the water that its rush cannot be described otherwise than furious; its course is straight forward, then it dashes suddenly round in another direction, attacking any other Synchaeta that may come in its way, and not at all particular as to species. I have seen it seize an unfortunate $S$. triophthalma with its jaws, carry it in its mouth and devour it without a moment's stop in its furious career. No other Synchaeta of my aquaintance is so fast in motion and so fierce of temper.' 
The Plymouth specimens seemed placid enough, though swimming fairly rapidly in spirals, but were never observed to attack other small organisms, or their own kind. Fierce nibbling attacks were, however, made on the Phaeocystis as already mentioned.

The males, which appeared in numbers during the middle of May, were a little smaller than the I $49 \mu$ specified by Rousselet, and the majority averaged I25 $\mu$. Like most other male rotifers, the males of this genus are devoid of digestive system, but possess a well-developed genito-urinary system. Most of the body cavity is occupied by the large sperm sac which opens into a small protuberance on the dorsal surface of the foot, forming a rudimentary penis. The movements of the male are even more vigorous and rapid than those of the female.

A final perplexing point regarding this species may be mentioned. Although the two frontal coronal prominences of the male, each with its crown of setae, were plainly visible (these are stated by Rousselet to be peculiar to the male of Synchaeta vorax), the three small tubular frontal antennae, also a characteristic feature of this male, could not be found.

The resting egg has an opaque shell, beset with many small pointed protuberances, and measures about $93 \mu$ in length (Fig. IG).

$S$. vorax appears to have a wide distribution, but it is quite probable, in view of the cosmopolitan habits of many rotifers, that further investigation of marine and brackish rotatorian faunas in foreign parts will reveal that many of the rotifers occurring round our coasts have a world-wide distribution. To date, $S$. vorax has been recorded from Dundee, Liverpool, Southport, Bergen, Lake Ladoga (fresh water), and the Suez canal. ${ }^{1}$

As in fresh water, planktonic rotifers in the sea doubtless become the prey of fish fry, but it would appear they also figure in the diet of other pelagic invertebrates, and $S$. vorax has been observed being devoured by Hydromedusae at Plymouth and also at Southport (Hollowday 1947).

\section{Encentrum marinum (Dujardin) (Fig. 2 B, C)}

Furcularia marina Dujardin, I84I. Histoire naturelle des Zoophytes etc., p. 649, pl. 22, fig. 4.

Distemma marina Gosse, 1887. Fourn. R. Micr. Soc., I887, p. 367. (Not Distemma marinum Ehr.)

Distemma platyceps Gosse, P. H., I887. Fourn. R. Micr. Soc., I887, p. 866, pl. I4, fig. I2.

Pleurotrocha marina Bergendal, D., 1892. Acta Univ. Lundensis, Vol. 28, No. 4, p. 50, pl. I, fig. I3.

Diglena marina N. von Hofsten, I9I2. Marine, Litorale Rotatorien etc. Zool. Bidr. Uppsala, Vol. I, p. 203.

\footnotetext{
1 Since this report was compiled, it has been found in brackish water at West Mersea, Essex, by A. L. Galliford and C. Rudlin.
} 
A strictly littoral-zone species, occurring in masses of algae in rock pools and brackish pools above the high-tide mark. It is also capable of living in fresh water as well as water of oceanic salinity.

The general appearance of the rotifer can be observed in the accompanying drawing, made from a rock pool specimen collected along the shores of Barn Pool and Mount Edgcumbe. It is doubtless common all round the shores of the Sound, although specimens were observed only in the above-mentioned region.

E. marinum has been recorded from Naples, Jacobshaven, Helsingfors, Bergen, Liverpool, and the Firth of Tay, also in salt and brackish water at Atlantic City, New Jersey, and Mount Desert Island, Maine. In fresh water, Royal Botanic Gardens, Regent's Park.

Several members of this genus are known to occur in salt pools and brackish waters.

$$
\text { Proales reinhardti (Ehrenberg) (Fig. 2D, E) }
$$

Furcularia reinhardti Ehrenberg, I833. Abh. Akad. wiss. Berlin, p. 208.

Distemma marinum Ehrenberg, I838. Infusionsth., p. 450, pl. 56, fig. 4. (Not Distemma marina Gosse.)

Mytilia tavina Hudson, C. T. \& Gosse, P. H., I886. The Rotifera, Vol. 2, p. IIO, pl. 26, fig. 8.

M. teresa Gosse, P. H., I887. Fourn. R. Micr. Soc., p. 3, pl. I, fig. 7 .

Notommata theodora Gosse, 1887. Fourn. R. Micr. Soc., p. 862, pl. I4, fig. 2.

Mytilia poecilops Gosse, 1887. Fourn. R. Micr. Soc., p. 869, pl. I5, fig. 21.

M. producta Gosse, 1887. Fourn. R. Micr. Soc., p. 870, pl. 15, fig. 22.

Notommata reinhardti Hudson \& Gosse, I889. The Rotifera. Suppl., p. 22.

Diops marina Bergendal, D., I892. Acta. Univ. Lundensis, Vol. 28, No. 4, p. 83, pls. 4 , 5, fig. 27 .

Pleurotrocha reinhardti von Hofsten, 1912. Zool. Bidr. Uppsala, Vol. I, p. I87, fig. I. Proales reinhardti Harring, H. K. \& Myers, F., 1924. Rotifera of Wisconsin. II. Trans. Wis. Acad. Sci. Arts, Let., p. 43I, pl. XVI, figs. 6-Io.

Few rotifers have been described so many times under different names by the same author as the one now known as Proales reinhardti (Ehrenberg).

A littoral, browsing species, $P$. reinhardt $i$ is common in rock pools, and in masses of Fucus.

All the main characteristics of the rotifer are so clearly shown in the accompanying illustrations drawn from Plymouth specimens, that little comment

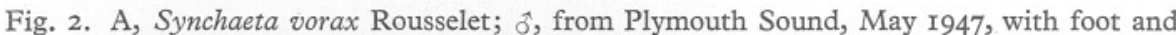
penis withdrawn; length I24 $\mu$; left dorso-lateral aspect (cf. Fig. IE). B, Encentrum marinum (Dujardin); $\$$, from rock pool, Mount Edgcumbe, Plymouth, with trophi $(t)$ protruded for browsing; length $c$. I65 $\mu$; right lateral aspect. C, the same, enlarged view of the trophi. D, Proales reinhardti (Ehrenberg);, , from rock pool, Jennycliff, Plymouth; length $260 \mu$; left lateral aspect. E, the same, $ᄋ$ from rock pool, Mount Edgcumbe, Plymouth; dorsal aspect. F, Trichocerca marina (Daday), 아 from the plankton, Plymouth Sound; body length I50 $\mu$; left lateral aspect. $d$, ingested diatoms; $e$, eye spot; $f$, foot; $g$, gastric gland; r.c., renal canal; r.s., retrocerebral sac; $s$, sperm sac; $t$, trophi; $v$, vitellarium. Vertical scales (different for each drawing) all represent lengths of $50 \mu$. 

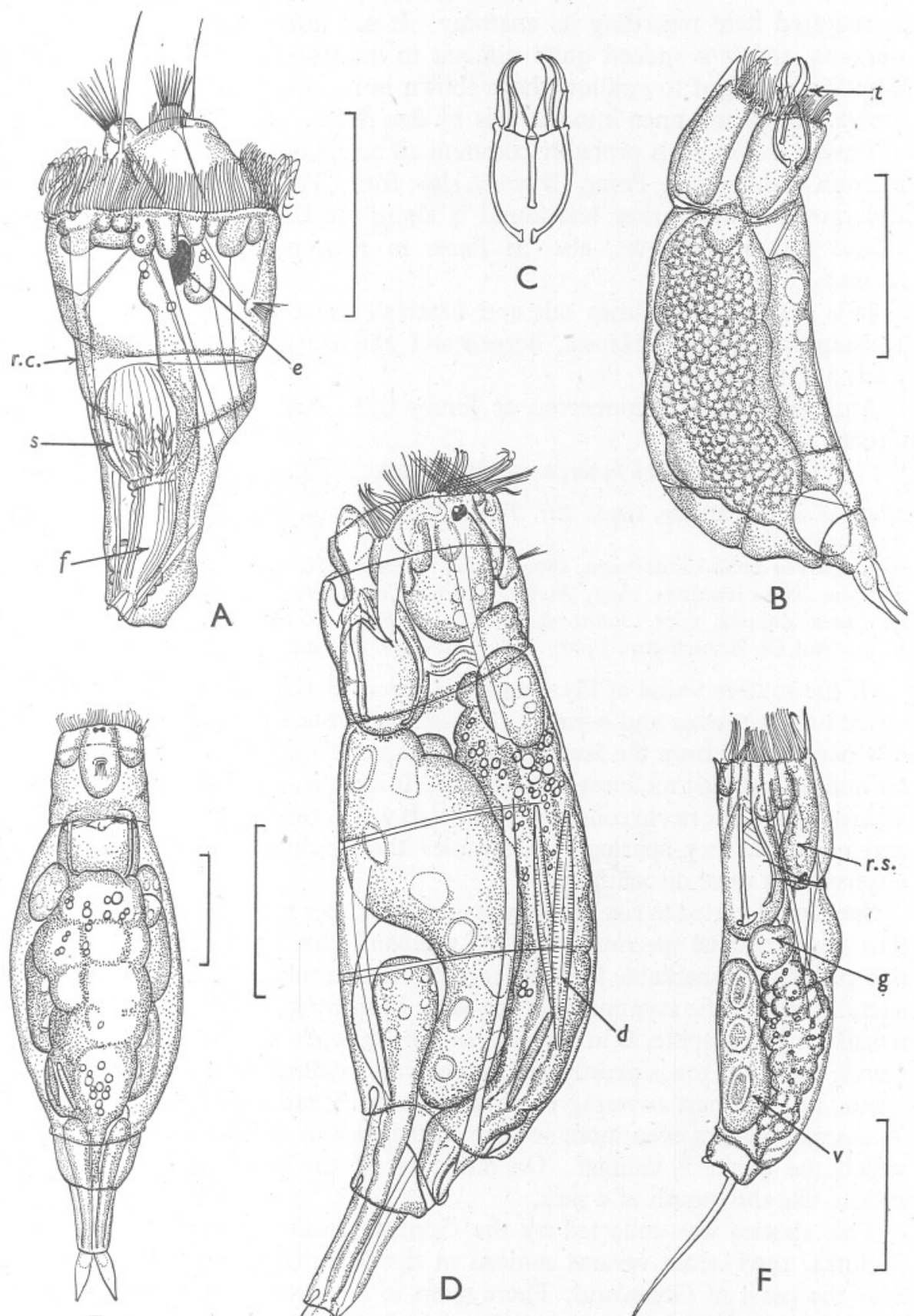

E
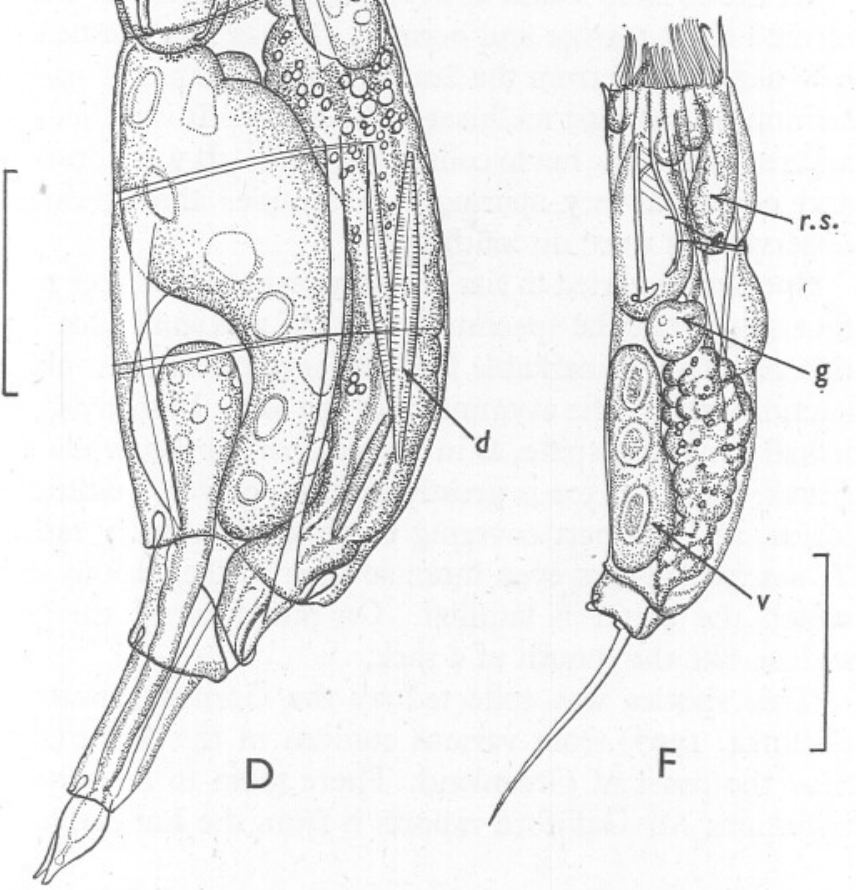

Fig. 2. 
is required here regarding its anatomy. It not infrequently swallows large diatoms, and it is indeed quite difficult to imagine how the specimen here depicted managed to swallow those shown in its stomach. The pedal glands are very long, and open into the toes by fine ducts.

Proales reinhardti is probably common all round our coast, Gosse recorded it from Oddicombe Point, Devon, also from Torbay, and tide-pools at Invergowrie. The writer has found it along the Cheshire coast, at Hilbre Island and at Leasowe, also in Fucus in rock pools at Bexhill-on-Sea, Sussex.

It is also reported from salt and brackish water at Copenhagen, Reval, Helsingfors, Wiborg, Hapsal, Bergen and Naples, and from brackish tidal pools at Atlantic City.

At Plymouth it is numerous at Jenny Cliff, Rum Bay, Barn Pool and Cremyl.

$$
\text { Trichocerca marina (Daday) (Fig. 2F) }
$$

Diurella marina Daday, I890. Ert. Termi. Kör., Vol. I9, No. I7, p. I6, pl. I, figs. 2 3,9 and ro.

Mastigocerca dubia Lauterborn, 1894. Wiss. Meeresunters. N.S., Vol. I, p. 213, fig. 2. Rattulus dubius Jennings, I902. Bull. U.S. Fish. Comm., Vol. 22, p. 340, pl. I4, fig. I33. R. henseni Zelinka, 1907. Rotatoria Plankton-Expedit., p. I9, pl. 2, figs. I-7.

R. marinus De Beauchamp, 1907. Bull. Soc. Zool. France, Vol. 32, p. I48.

Of the rotifers found at Plymouth this species is the only one which can be termed truly marine and oceanic. It was first noticed by the writer in coarse tow-net samples from the Sound in the summer of 1946, when it was observed swimming amongst medusae of Obelia sp. It is rather a small rotifer, however, and requires a fine net to collect it as a rule. It was not seen again until May I947, and occurred very sparingly in samples throughout June, after which all observations were discontinued.

Specimens varied in size; most measured just over $150 \mu$ including the single foot spine, but the specimen depicted was somewhat larger. The members of this genus are remarkable for their asymmetrical trophi, which are adapted for suction, and for the asymmetry of the toes. In many species one toe only is left, usually as a long spine, as in Trichocerca marina, while in other members of the genus, the other toe is greatly reduced or very rudimentary. The front of the lorica, i.e. that part covering the head, is usually rather flexible, but that of T. marina appears even more so than in the various fresh-water species with which the writer is familiar. On retraction of the head it can be drawn to a close like the mouth of a sack.

This species was collected by the German Plankton Expedition of 1895 (Zelinka, 1907) from various stations in the Atlantic, being most numerous. near the coast of Greenland. There seem to be very few records of its distribution; Mr Galliford reports it from the Lancashire coast. 


\section{The Plymouth Rotatorian Fauna compared with that of Liverpool}

It must be admitted that the writer was somewhat disappointed at the apparent poverty of the Plymouth rotatorian fauna as compared with that of Liverpool and neighbouring stations along the Lancashire and Cheshire Coast, reported by Galliford (1945, 1946), although, as previously remarked, further investigation at Plymouth would probably add several species to the present list. Compared with the six species found at Plymouth, Galliford has recorded no less than thirty-five species as occurring in salt and brackish waters at Liverpool. Although no figures are available for comparison, degree of salinity may be a controlling factor, and it is hoped that further details regarding the comparative salinity of the Plymouth and Liverpool habitats will be assembled in due course, but it is here vitally necessary to stress certain facts regarding the application of the term 'marine' to the rotifers occurring round our coasts, as well as in continental coastal waters in general.

It is probably a little premature at this stage of our knowledge to make broad generalizations on the distribution of coastal Rotifera, for so little collecting has yet been done, but it is noticeable that most of the species referred to by various workers as 'marine rotifers' are in fact confined to estuarine waters of low salinity, being more numerous in the upper reaches of creeks and in 'marine lakes', such as that at Southport, which is occasionally replenished from the sea, but which is constantly having the salinity lowered by rain. Pools above high-water mark which receive spray and rain are also favourite haunts of these brackish rotifers. The extensive analytical details given by Zelinka (1907) are apt to be misleading, for many of his salt-water records are really from brackish habitats, and should be considered with caution. Although Synchaeta vorax and S. littoralis have been found in the open waters of the Sound, the Sound itself, like Liverpool Bay, and the various other stations at which coastal rotifers have been studied in these islands, has numerous sources of fresh water emptying into it. At Bexhill-on-Sea, Sussex, where there are no rivers close at hand, extensive collecting with hand-net and tow-net, inshore and on the open sea, revealed no rotifers whatsoever, although Proales reinhardti occurred in Fucus in rock pools. One single specimen of Synchaeta, contracted and otherwise unrecognizable, was taken in the incoming tide.

Certain rotifers however, among them Proales reinhardti and Encentrum marinum, appear to inhabit salt, brackish, and fresh-water habitats, although it is not known whether individuals are capable of withstanding transfer from one habitat to the other. That both species are found in all three situations however, is quite certain. Some of the brackish species seem very susceptible to osmotic changes; thus Rousselet (1902) records that Synchaeta triophthalma quickly succumbs on immersion in fresh water. On the other hand, it does not appear to favour waters of high salinity. 
As to the seasonal appearances, life histories, and general ecology of these coastal rotifers, little or nothing is known, and the field presents many interesting problems worthy of further investigation.

\section{SUMMARY}

Six species of rotifer, including one oceanic species and representing four genera, are recorded for the first time from Plymouth. Remarks are made on various interesting features of their anatomy, details are given of their times of occurrence at Plymouth, with notes on their location and known distribution in other parts of the British Isles, and in foreign waters.

Attention is called to the apparent poverty of the Plymouth marine and brackish-water Rotifera as compared with that of Liverpool, investigated at length by Galliford. It is stressed that no exact conclusions as to the reason for this can be made until after a more exhaustive survey, as some likely habitats adjacent to the Sound were not investigated. Attention is also called to the caution which must be exercised in terming rotifers marine, as most of those collected in coastal waters appear at present to be confined to areas where a considerable amount of fresh water is discharged into the sea. At least two species, one of which occurs in the Sound in May, are known to be truly oceanic, having been found in mid-Atlantic.

It is suggested that 'brackish' and 'estuarine' are the terms most applicable to the majority of coastal rotifers in the present state of our knowledge.

\section{REFERENCES}

Claus, C., 1876. Ueber die Organisation und die systematische Stellung der Gattung Seison Grube. Festschr. Zool.-Bot. Ges. Wien, pp. 74-88, 2 pls.

EHRENBERG, C. G.,I834. Dritter Beitrag zur Erkenntnis grosser Organisation in der Richtung des kleinsten Raumes. Abh. Akad. Wiss., Berlin for I833, p. 220.

I838. Die Infusionsthierchen als vollkommene Organismen. Leipzig.

GALLIFORD, A. L., I945. A contribution to the rotifer fauna of the Liverpool area with a description of a new species. Proc. Liverpool Naturalists' F.C., pp. I I-I6, I pl.

- I946. Additions to the rotifer fauna of the Liverpool area. Proc. Liverpool Naturalists' F.C., pp. 6-9.

Gosse, P. H., I856. Tenby: a Sea-Side Holiday. London.

GRUBE, A. E., I859. Neue mikroskopische Thierform. Fb. Schlesischen Ges. Vaterl. Cultur, Bd. 37, p. 25.

Hollowday, E. D., I946. Introduction to the study of the Rotifera. Part IV. Drawing Rotifera. The Microscope and Entomological Monthly, Vol. 6, pp. 3-9.

- 1947. On the capture of marine Rotifera as food by Hydromedusae. Fourn. Quekett Micr. Club, Ser. 4, Vol. 2, pp. 190-2.

Hudson, C. T., \& Gosse, P. H., I886. The Rotifera; or wheel-animalcules. Vols. I and II. I 28 and I44 pp. (also plates). London.

- I889. The Rotifera; or wheel-animalcules: Supplement, 64 pp. London.

LANKESTER, E. RAY, I868. Note on the Synaptae of Guernsey and Herm, and a new parasitic rotifer. Quart. F. Micr. Sci., Vol. 8, pp. 53-5. 
Marine Biological Association, I93i. Plymouth Marine Fauna, 2nd ed.

Remane, A., I929. Rotatoria. Die Tierwelt der Nord- und Ostsee. L. xvi, T. vire. I56 pp. Leipzig.

RousselET, C. F., I902. The genus Synchaeta: a monographic study, with descriptions of five new species. Fourn. R. Micr. Soc., pp. 269-90, 393-4II, pls. III-VIII.

SCOTtish Marine Biological Association, I928. Annual Report, 1927-28. [Faunistic Notes, pp. II-I3.]

WULFERT, K., I942. Ueber die Meeres- und Brackwasser-Rotatorien in der Umgebung von Rovigno D'Istria. Thalassia, Bd. Iv, H. 7, 26 pp., 6 pl.

ZelinkA, C., I907. Die Rotatorien der Plankton-Expedition, Ergeb. der PlanktonExpedition der Humboldt-Stiftung, Bd. II, H.a., 82 pp., 3 pl. 